\title{
IMPLEMENTASI AKAD MURABAHAH BERBASIS MARGIN PADA MASA PANDEMI COVID-19
}

\author{
Awin Rahma Zulvia', Nawirah ${ }^{2}$ \\ 1,2 Fakultas Ekonomi, Universitas Islam Negeri Maulana Malik Ibrahim Malang \\ Jalan Gajayana No. 50, Dinoyo, Malang, Jawa Timur, 65144, Indonesia
}

$\triangle$ Corresponding Author:

Nama Penulis: Nawirah

E-mail: nawirah@uin-malang.ac.id

\begin{abstract}
Researchers choose the research objects in BRI Syariah Malang Branch because they have high customer trust. Financing products at BRI Syariah Malang Branch one of them is murabahah. Murabahah is a product to buy and sell financing in cash and credit in accordance with Islamic principles. This study aims to find out the effect of the covid-19 pandemic on the use of murabahah margins. This research uses qualitative methods with two approaches, namely interviews and in-depth observations. The results of this study confirm that murabahah financing is the most desirable financing in the pandemic period of $93.2 \%$ and the most effective murabahah margin used during pandemics is the annuity method. The determination of this margin is in accordance with DSN Fatwa No: 84/DSN-MUI/XII/2012 on the determination of Murabahah Financing Benefits.
\end{abstract}

Keywords: Murabahah; Margin; Covid-19 Pandemic

Abstrak

Penelitian ini bertujuan untuk mengetahui penggunaan margin murabahah pada masa pandemi covid-19. Peneliti memilih objek penelitian di PT. BRI Syariah. Produk pembiayaan pada PT. BRI Syariah salah satunya yaitu murabahah. Murabahah merupakan produk jual beli pembiayaan dalam bentuk tunai maupun kredit sesuai prinsip islam. Penelitian ini menggunakan metode kualitatif dengan dua pendekatan yaitu wawancara dan observasi mendalam. Hasil penelitian ini mengkonfirmasi bahwa pembiayaan murabahah merupakan pembiayaan yang paling diminati masyarakat pada masa pandemi sebesar 93,2\% dan margin murabahah yang paling efektif digunakan pada masa pandemi yaitu metode anuitas. Penentuan margin ini sesuai dengan Fatwa DSN No: 84/DSN-MUI/XII/2012 tentang penentuan Keuntungan Pembiayaan Murabahah.

Kata kunci: Murabahah; Margin; Pandemi Covid-19 


\section{PENDAHULUAN}

Indonesia merupakan negara dengan mayoritas penduduknya memeluk agama Islam. Hal ini menjadi penyebab sektor ekonomi berkembang pesat pada Lembaga Keuangan Syariah (LKS) (Awwalunnisa, 2021; Soemitra, 2017). LKS berkembang sejak dekade 90 -an yang ditandai berdirinya Bank Muamalat sebagai pelopor di Indonesia, bank syariah sampai sekarang terus mengalami perkembangan yang signifikan (Marimin \& Romdhoni, 2017; Oktaviani Satriyanti, 2012). Data Statistik Perbankan Syariah (SPS) menunjukkan dalam lima tahun terakhir mengenai perkembangan LKS. LKS di Indonesia mengalami peningkatan di tahun 2020. Data SPS bulan Juni 2020 menjelaskan ada 498 Bank Umum Syariah serta 162 Unit Usaha Syariah yang beroperasi (SPS, 2020). Gambar 1 menunjukkan perkembangan Lembaga Keuangan Syariah di tahun 2015-2019.

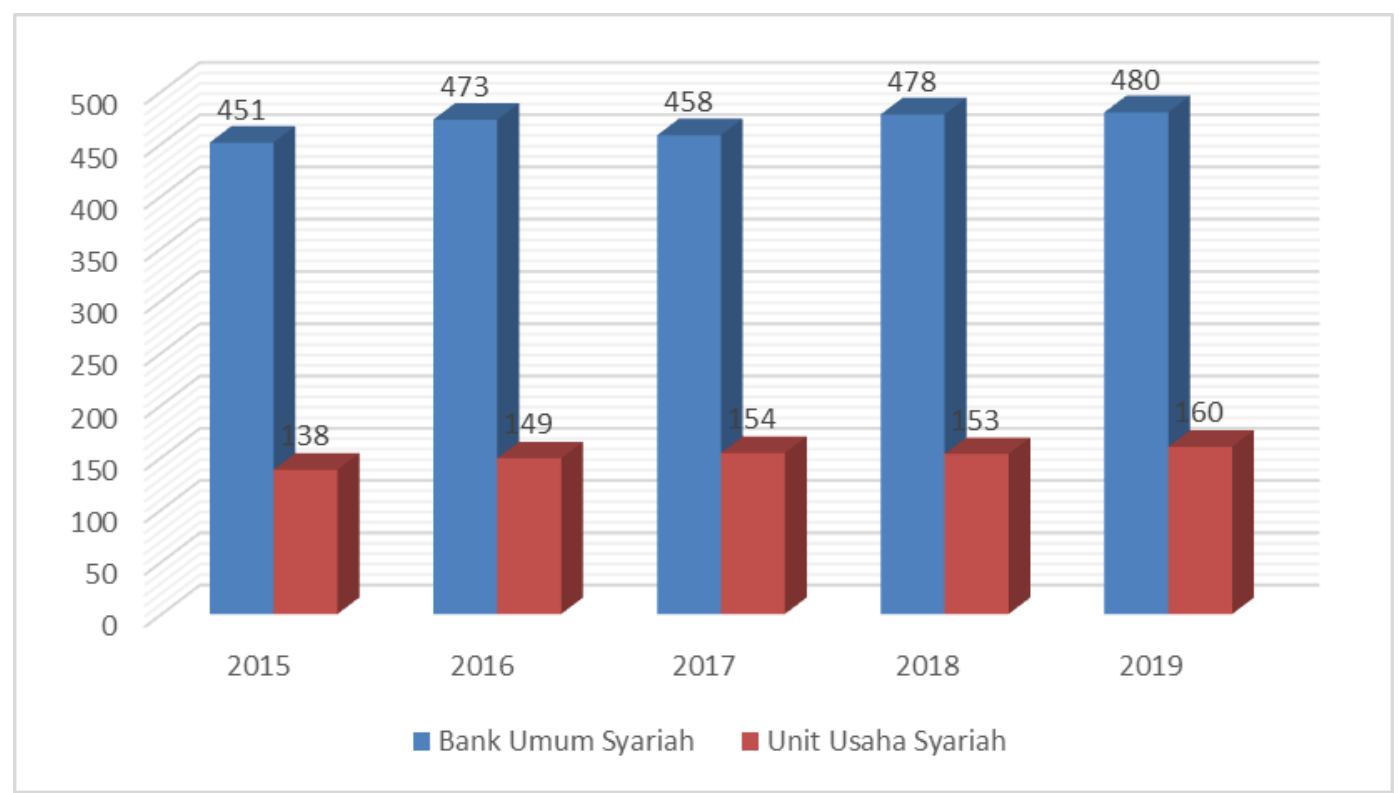

Gambar 1. Data Perkembangan Lembaga Keuangan Syariah Tahun 2015-2019 Sumber : Statistik Perbankan Syariah (OJK, 2019)

Sejak bulan Maret 2020 pemerintah membatasi aktivitas diluar ruangan untuk mencegah terjadinya penyebaran virus Covid-19 (Bramantyo \& Rahman, 2021; Mastura \& Santaria, 2020). Hal ini tentu sangat berdampak terhadap aktivitas ekonomi termasuk pada Lembaga Keungan Syariah. Serta keputusan pemerintah pada bulan April 2020 yaitu Indonesia mengalami darurat bencana pandemi Covid-19 sesuai keputusan presiden nomor 12 tahun 2020 (Mastura \& Santaria, 2020).

Lembaga keuangan syariah seperti bank umum syariah memberikan peran yang cukup baik dalam rangka mempertahankan sektor ekonomi di tengah pandemi Covid-19. Pratiwi \& Septiarini (2014) menawarkan produk- 
produknya terutama produk pembiayaan yang banyak diminati masyarakat. Tujuannya adalah mempertahankan usahanya atau membuka usaha untuk sekedar menyambung hidup (Hidayat \& Nurhayati, 2018). Data SPS pada bulan Maret hingga Juni tahun 2020 dari 14 Bank Umum Syariah ditunjukkan pada Gambar 2.

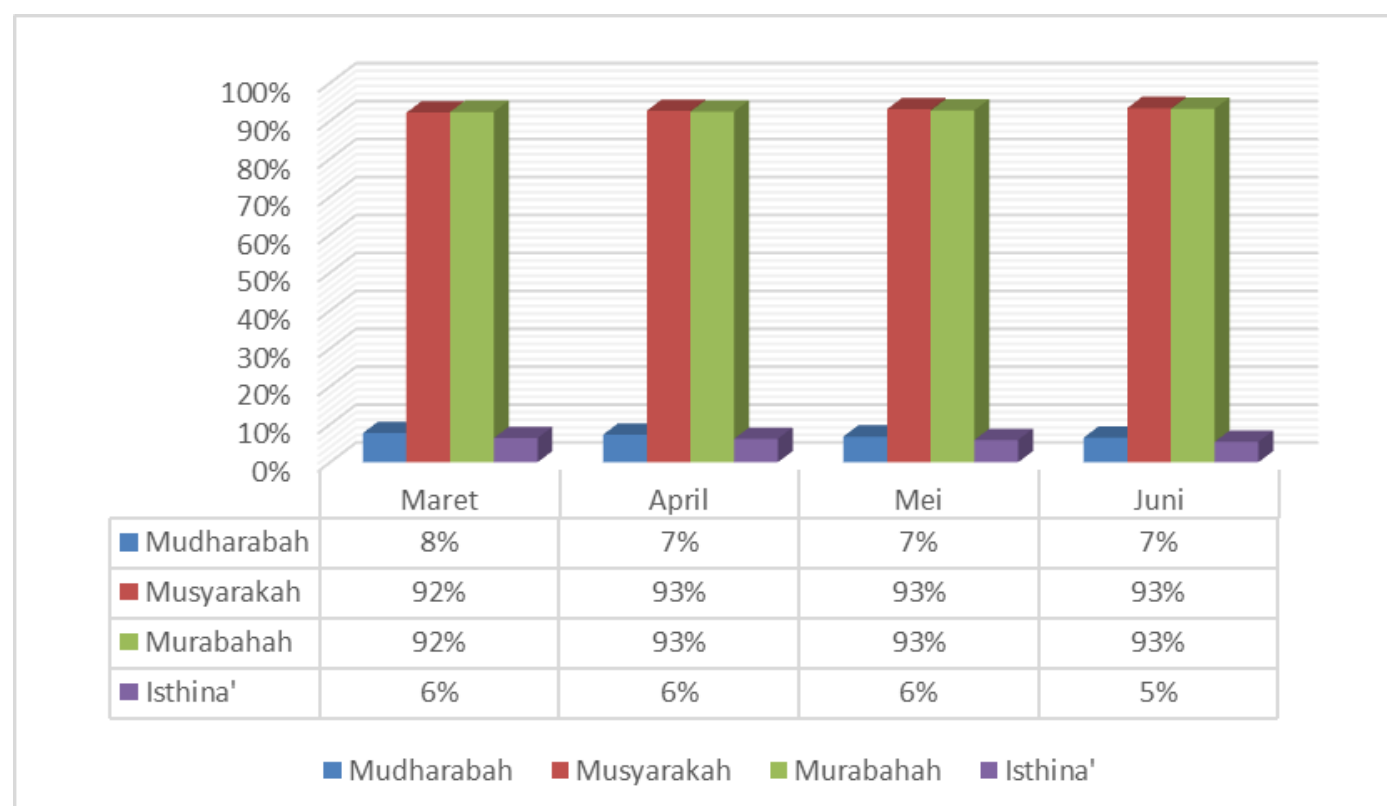

Gambar 2. Komposisi Pembiayaan Bank Umum Syariah Bulan Maret-Juni Tahun 2020 Sumber : Statistik Perbankan Syariah (0JK, 2020)

Murabahah adalah pembiayaan dengan akad jual beli yang terjadi di lembaga keuangan syariah. Nasabah sebagai pihak pembeli dalam akad ini, sedangkan lembaga keuangan syariah sebagai penjual. Murabahah dapat dilakukan dengan dua acara yaitu dengan pesanan atau tanpa pesanan (Amrullah, 2016; Anik, 2017; Soemitra, 2017). Murabahah tanpa pesanan dilakukan hanya antara penjual dan pembeli yaitu tanpa pihak ketiga. Sedangkan murabahah dengan pesanan yaitu murabahah yang dilakukan oleh penjual dan pembeli, namun penjual harus melakukan pesanan barang kepada pihak ketiga sesuai perjanjian dengan pembeli (Farid, 2013).

Ilustrasi akad murabahah jika Lembaga Keuangan Syariah membeli barang berdasarkan pesanan nasabah kemudian di jual kepada nasabah maka Lembaga Keuangan Syariah mendapat keuntungan atau margin. Metode perhitungan margin pada pembiayaan murabahah terdapat metode anuitas serta metode proposional (Habibah \& Nikmah, 2017; Octariza, 2018). Jika melihat dalam kenyataan sehari-hari sebagian besar Lembaga Keuangan Syariah dalam menentukan margin menggunakan metode anuitas. Hal ini dikarenakan Lembaga Keuangan Syariah menginginkan profitabilitas yang tinggi dalam laporan keuangan. Profitabilitas tinggi berguna untuk going 
concern Lembaga Keuangan di Indonesia (Sholikah \& Miranti, 2020). Berdasarkan tersebut, maka menjadi hal yang penting bagi Lembaga Keuangan Syariah untuk memperhatikan nilai profitabilitasnya.

Penelitian ini dilakukan di Bank Republik Indonesia Syariah (BRIS) Cabang Malang karena persebaran BRIS lebih cepat daripada perbankan syariah di kota Malang seperti data yang ditunjukkan pada Gambar 3. Hal ini juga didukung dengan hasil wawancara yang dilakukan oleh peneliti dengan Bapak Prasetya selaku Manager Marketing BRIS Caabang Malang pada 19 Agustus 2020 pukul 08.41 WIB, yang menyatakan:

"BRI Syariah menggunakan metode anuitas yang dihalalkan oleh Dewan Syariah Nasional serta dengan alasan pengaruh metode anuitas terhadap pertumbuhan bank syariah sangat signifikan."

Dewan Syariah Nasional Majelis Ulama Indonesia mengeluarkan putusan Fatwa Dewan Syariah Nasional No: 84/DSN-MUI/XII/2012 tentang Metode Pengakuan Keuntungan Al-Tamwil Bi Al-Murabahah di Lembaga Keuangan Syariah, yakni "Metode pengakuan keuntungan murabahah dan pembiayaan murabahah boleh dilakukan secara proporsional dan secara anuitas dengan mengikuti ketentuan-ketentuan dalam fatwa ini". Sedangkan dalam PSAK No.102 hanya menjelaskan mengenai pengakuan margin murabahah secara langsung saat penyerahan barang, secara proposional. PSAK No.102 tidak menjelaskan secara jelas untuk metode perhitungan margin murabahah. Berdasarkan penjelasan diatas maka penting mengetahui metode perhitungan yang paling efektif digunakan. Maka peneliti tertarik melakukan penelitian tentang implementasi akad murabahah berbasis margin pada masa pandemi Covid-19.

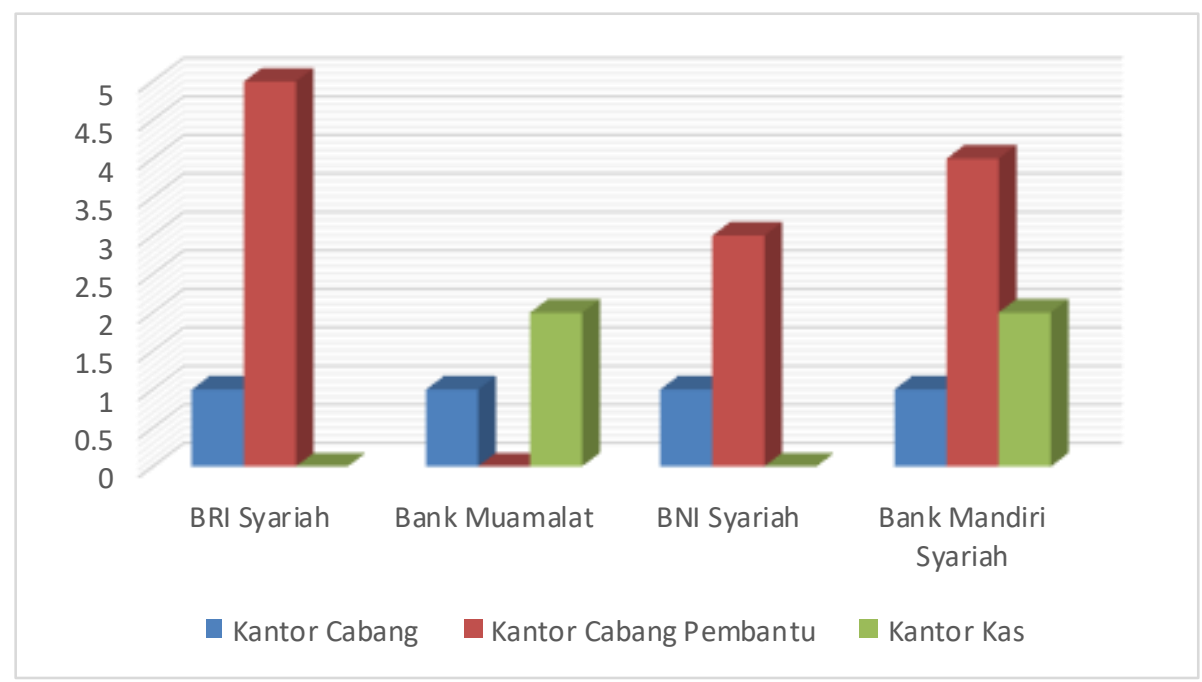

Gambar 3. Persebaran Bank Umum Syariah di Malang Sumber : Statistik Perbankan Syariah (OJK, 2020) 


\section{KAJIAN PUSTAKA}

Sejak tahun 1999 Lembaga Keuangan Syariah telah berkembang cukup pesat terutama perbankan syariah. Hal ini seiring dengan berlakunya Undang-undang nomor 10 tahun 1998 yang merupakan penyempurnaan dari undang-undang nomor 7 tahun 1992 tentang perbankan (Wiroso, 2010). Sedangkan perbankan syariah mulai berkembang dengan berdirinya bank Muamalat Indonesia pada dekade 90-an.

Lembaga Keuangan Syariah berhubungan erat dengan akuntansi syariah yang didefinisikan sebagai pengakuan, pengukuran, pencatatan transaksi, pengungkapan hak-hak dan kewajiban yang adil. Sejatinya perkembangan akuntansi syariah tidak lepas dari perkembangan lembaga keuangan syariah. Perkembangan akuntansi syariah dimulai sejak tahun 1999 yang diperkasai oleh Bank Indonesia dengan membentuk tim penyusun PSAK Bank Syariah yang tertuang dalam Surat Keputusan Gurbernur Bank Indonesia Nomor 1/16/KEP/DGB/1999, yang meliputi unsur-unsur dari Bank Indonesia dan Ikatan Akuntan Indonesia (IAI) (Muchlis, 2019; Qiyamah, 2015).

Praktik akuntansi sebenarnya sudah ada sejak masa Rasulullah seperti yang dijelaskan dalam surat Al-Baqarah ayat 282 berbunyi:

"Hai orang-orang yang beriman, apabila kamu bermu'amalah tidak secara tunai untuk waktu yang ditentukan, hendaklah kamu mendiskusikannya...".

Sehingga dalam hal ini perintah Allah SWT untuk mencatat transaksi tidak tunai yang mendorong setiap orang untuk senantiasa menggunakan dokumen berupa bukti transaksi (Nawawi, 2012). Salah satu jenis pembiayaan di lembaga keungan syariah yaitu murabahah. Murababah merupakan salah satu produk yang paling popular dalam praktik pembiayaan pada perbankan syariah. Selain mudah perhitungannya, baik bagi nasabah maupun bagi pihak bank, produk ini memiliki beberapa kesamaan dengan sistem kredit pada perbankan konvensional. Meskipun demikian, secara prinsip, murabahah sangat berbeda jauh dengan suku bunga dalam perbankan konvensional (Kamaliyah, 2018).

Penggunaan standar akuntansi murabahah bergantung pada metode pengakuan pendapatan murabahah. Pengakuan pendapatan dapat menggunakan metode anuitas wajib menggunakan standar akuntansi berdasarkan PSAK 55 Tahun 2011 tentang instrument keuangan: pengakuan dan pengukuran, PSAK 50 Tahun 2010 tentang instrument keuangan: penyajian, PSAK 60: instrumen keuangan: pengungkapan dan PSAK lain yang relevan, sepanjang tidak bertentangan dengan prinsip Syariah (Fatmawati \& Mulawarman, 2014). Namun pada tahun 2008 tepatnya pada 1 Januari 2008 
muncul PSAK 102 yang menggantikan PSAK 59. Dalam PSAK 102 untuk pengakuan, pengukuran, penyajian, dan pengungkapan murabahah terdapat dalam PSAK 102 sehingga untuk metode metode pengakuan pendapatan menggunakan metode proposional. Sedangkan untuk metode perhitungan margin belum dijelaskan dalam PSAK 102. Selama ini dalam penerapan sehari-harinya lembaga keuangan syariah menggunakan metode perhitungan secara anuitas atau proposional (Ramadani \& Suprayogi, 2017).

Pengakuan margin murabahah dalam PSAK 102 pada paragraf 23 yaitu pada saat awal penyerahan barang, diakui secara proposional setiap membayar angsuran dan diakui pada akhir ketika pembayaran sudah lunas. Berhubungan dengan kondisi pandemi virus covid-19 mempengaruhi kinerja Lembaga Keuangan Syariah. Pandemi covid-19 memberikan dampak pada lembaga keuangan syariah di Indonesia yaitu perlambatan penyaluran pembiayaan, penurunan kualitas asset, serta pengetatan margin bersih (Safitri et al., 2021; Triningsih, 2021).

\section{METODE}

Penelitian ini menekankan pada pendekatan kualitatif dengan pendekatan deskriptif yang bertujuan menjelaskan perlakuan akuntansi murabahah berbasis margin pada masa pandemi covid-19 di Bank Republik Indonesia Syariah (BRIS) Cabang Malang. Subjek penelitian yang dipilih peneliti yaitu Bapak Irawan Setia Budi selaku Manager Financing \& Supporting dan Bapak Tri Prasetyo Utomo Selaku Manager Marketing. Penelitian ini diperkuat dengan data sekunder yang diperoleh melalui laporan keuangan bulan Maret - Juli 2020 yang terpublik serta transaksi terkait murabahah dan latar belakang BRIS Cabang Malang yang diperoleh dari pihak BRIS Cabang Malang.

Peneliti memperoleh data dengan cara wawancara dan observasi. Wawancara dilakukan peneliti kepada Bapak Irawan Setia Budi selaku Manager Financing \& Supporting serta Bapak Tri Prasetyo Utomo Selaku Manager Marketing. Peneliti melakukan observasi dengan cara mengamati transaksi yang berhubungan dengan murabahah pada BRIS Cabang Malang. Dilanjutkan dengan proses dokumentasi dengan cara mengumpulkan laporan keuangan BRIS yang terdapat pada website (BRIS, 2020).

Analisis data dalam penelitian ini dilakukan dengan beberapa tahap sebagai berikut: 1) Melakukan proses identifikasi transaksi terkait akad murabahah pada BRIS Cabang Malang; 2) Melakukan proses identifikasi perhitungan margin murabahah yang digunakan oleh BRIS Cabang Malang; 3) Melakukan perbandingan perhitungan margin dengan metode anuitas dan proposional pada masa pandemi covid-19 di BRIS Cabang Malang; 4) Proses 
implementasi PSAK 102 dalam proses perhitungan margin murabahah saat pandemi covid-19 di BRIS Cabang Malang.

\section{HASIL DAN PEMBAHASAN}

BRIS Cabang Malang memliki beberapa produk yang menggunakan akad murabahah yaitu KPR BRIS iB, KPR Sejahtera BRIS iB, KKB BRIS iB, KMF Pra Purna BRIS iB, KMF BRIS iB, Gadai Faedah BRIS iB, dan Mikro BRIS. Adapun persyaratan secara umum untuk mengajukan pembiayaan murabahah sebagai berikut: 1) calon nasabah merupakan Warga Negara Indonesia (WNI); 2) Tenaga kerja/pegawai tetap yang memiliki masa kerja minimal dua tahun; 3) calon nasabah merupakan dokter, dokter spesialis dan bidan atau yang berprofesi dibidang kesehatan; 4) Wiraswasta/Pengusaha yang memiliki usaha aktif dan telah beroperasional lebih dari 5 tahun; 5) calon nasabah minimal berusia 21 tahun (pada saat menerima pembiayaan), dan maksimum usia pensiun 65 tahun untuk profesi dokter (pada saat jatuh tempo pembiayaan); 6) Output track record BI Checking dan DHBI nasabah menunjukkan nilai yang baik; 7) calon nasabah memenuhi persyaratan asuransi jiwa pembiayaan; 8) calon nasabah diwajibkan memiliki/membuka rekening tabungan di Bank BRIsyariah; 9) Jika total pembiayaan melebihin50 juta Rupiah, maka calon nasabah harus menyertakan Nomor Pajak Wajib Pajak (NPWP) orang pribadi (brisyariah, 2020).

Prosedur Pengajuan Pembiayaan Murabahah sebagai contoh produk KKB BRIS iB. Misalkan nasabah datang ke BRIS untuk mengajukan pembiayaan murabahah guna pembelian sebuah mobil. Nasabah mengajukan Kartu Tanda Penduduk dan Kartu Keluarga serta sejumlah uang untuk uang muka. Jika nasabah belum memiliki rekening BRIS maka wajib untuk mengajukan pembukaan rekening terlebih dahulu. Customer service (CS) memberikan formulir pengajuan pembiayaan untuk diisi nasabah. Setelah itu CS menyakan terkait pekerjaan serta gaji nasabah. Setelah pihak BRIS melakuakan BI checking terhadap data nasabah yang telah disetorkan. Apabila akad murabahah terjadi maka dalam akad tersebut terdapat harga perolehan yaitu harga beli BRIS dari pihak pertama misalnya, dealer, margin atau keuntungan serta harga jual. Setelah nasabah sepakat dengan ketentuan tersebut, maka nasabah yang mengajukan pembiayaan murabahah pada BRIS merupakan murabahah tangguhan (Brisyariah, 2020).

Dalam penelitian ini peneliti memberikan simulasi pembiayaan murabahah berdasarkan hasil wawancara dengan Bapak Irawan Setia Budi pada 13 November 2020 Pukul 16.30 WIB:

"Bapak Andi merupakan karyawan swasta yang akan mengambil rumah di Permata Pelangi secara kredit. Pihak Permata Pelangi memberikan 
beberapa bank syariah salah satunya BRIS Cabang Malang. Setelah dilakukan kesepakatan harga anatar pihak Permata Pelangi dengan Bapak Andi dan beliau memilih BRIS Cabang Malang. Dengan kesepakatan ini maka Bapak Andi memberikan kuasa kepada BRIS Cabang Malang untuk membeli rumah tersebut. Lalu pihak bank melakukan pembiayaan atas rumah tersebut. Secara prinsip rumah tersebut milik bank waluapun secara hak rumah tersebut milik Bapak Andi. Karena secara prinsip rumah tersubut milik bank maka bank akan melakukan akad murabahah (jual-beli) dengan Bapak Andi yaitu dengan peran BRIS sebagai penjual dan Bapak Andi sebagai pembeli. BRIS Cabang malang dalam transaksi menggunakan margin anuitas sebagai metode perhitungan marginnnya."

Berikut perhitungan margin hingga angsuran Bapak Andi :

1. Berdasarkan perhitungan metode anuitas untuk nilai pokok Rp.100.000.000 dengan margin Rp.50.000.000 dan jangka waktu 5 tahun diperoleh effective rate of return sebesar $15,24 \%$.

2. Perhitungan angsuran, pokok, dan margin anuitas, ditunjukkan pada Tabel 1.

Tabel 1. Perhitungan angsuran, pokok dan margin

\begin{tabular}{llll}
\hline Tahun & Angsuran (Rp) & Pokok (Rp) & Margin \\
\hline 1 & $30,000,000$ & $14,760,000$ & $15,240,000$ \\
\hline 2 & $30,000,000$ & $17,010,000$ & $12,990,000$ \\
\hline 3 & $30,000,000$ & $19,600,000$ & $10,400,000$ \\
\hline 4 & $30,000,000$ & $22,560,000$ & $7,410,000$ \\
\hline 5 & $30,000,000$ & $26,030,000$ & $3,970,000$ \\
\hline
\end{tabular}

Sumber: Data diolah peneliti (2020)

3. Setelah terjadi kesepakatan maka BRIS melakukan pembayaran kepada pihak Permata Pelangi untuk pembelian rumah sesuai kriteria Bapak Andi, maka jurnalnya sebagai berikut :

$$
\begin{aligned}
& \text { Persediaan Murabahah Rp.100,000,000 } \\
& \quad \text { Kas }
\end{aligned}
$$

4. Saat Bapak andi memutuskan membeli rumah dengan mengajukan pembiayaan kepada BRIS dan terjadi kesepakatan akad murabahah, maka jurnalnya sebagai berikut :

$\begin{array}{lr}\text { Piutang Murabahah } & \text { Rp. 150,000,000 } \\ \text { Persediaan murabahah } & \text { Rp. 100,000,000 } \\ \begin{array}{l}\text { Margin murabahah } \\ \text { tangguhan }\end{array} & \text { Rp. 50,000,000 }\end{array}$


5. Saat pembayaran angsuran pada tahun pertama Bapak Andi kepada BRIS Cabang Malang

$\begin{array}{lcr}\text { Kas } & \text { Rp. 30,000,000 } & \\ \quad \text { Piutang murabahah } & \text { Rp. 30,000,000 } \\ \begin{array}{l}\text { Margin murabahah } \\ \text { tangguhan }\end{array} & \text { Rp. 15,240,000 } & \\ \quad \begin{array}{l}\text { Pendapatan margin } \\ \text { murabahah }\end{array} & \text { Rp. 15,240,000 }\end{array}$

6. Saat pembayaran angsuran pada tahun kedua Bapak Andi kepada BRIS Cabang Malang

$\begin{array}{lcc}\text { Kas } & \text { Rp. 30,000,000 } & \\ \quad \text { Piutang murabahah } & & \text { Rp. 30,000,000 } \\ \begin{array}{l}\text { Margin murabahah } \\ \text { tangguhan }\end{array} & \text { Rp. 12,990,000 } & \\ \quad \begin{array}{l}\text { Pendapatan margin } \\ \text { murabahah }\end{array} & \text { Rp. 12,990,000 }\end{array}$

7. Saat pembayaran angsuran pada tahun ketiga Bapak Andi kepada BRIS Cabang Malang
Kas
Rp. $30,000,000$
Piutang murabahah
Rp. 30,000,000
Margin murabahah
tangguhan
Pendapatan margin
murabahah
Rp. 10,400,000

8. Saat pembayaran angsuran pada tahun keempat Bapak Andi kepada BRIS Cabang Malang

Kas

Piutang murabahah

Margin murabahah

tangguhan

Pendapatan margin

murabahah
Rp. $30,000,000$

Rp. 30,000,000

Rp. $7,410,000$

9. Saat pembayaran angsuran pada tahun kelima Bapak Andi kepada BRIS Cabang Malang

$$
\text { Kas }
$$

Piutang murabahah
Rp. 30,000,000

Rp. $30,000,000$ 
Awin Rahma Zulvia: Implementasi Akad Murabahah Berbasis Margin

$\begin{array}{ll}\begin{array}{l}\text { Margin murabahah } \\ \text { tangguhan }\end{array} & R p .3,970,000 \\ \quad \begin{array}{l}\text { Pendapatan margin } \\ \text { murabahah }\end{array} & R p .3,970,000\end{array}$

Berdasarkan simulasi diatas BRIS dalam pengakuan dan pengukuran murabahah sesuai dengan PSAK 102 pada paragraf 18 dimana BRIS Cabang Malang saat memperoleh asset murabahah mengakui sebagai persediaan murabahah sebesar harga perolehan dari pihak pertama. Namun jika persediaan tersebut mengalami kerusakan atau kondisi lainnya sebelum diserahkan kepada nasabah tidak diakui sebagai beban karena BRIS Cabang Malang hanya menjurnal satu kali saat pencairan saja, sehingga dalam hal ini BRIS Cabang Malang tidak sesuai dengan PSAK 102.

Pada saat pengakuan margin BRIS tidak mengakui saat penyerahan persediaan murabahah ke nasabah karena jenis murabahah yang diterapkan murabahah tangguh. Sehingga penerpan PSAK 102 pada paragraf 23a dan 23b tidak sesuai dengan BRIS Cabang Malang. Pernyataan ini di dukung dengan hasil wawancara peneliti dengan Bapak Prasetya selaku Manager Marketing pada 11 Agustus 2020 pukul 12.00 WIB:

" Jadi BRIS hanya menyediakan layanan murabahah tangguhan yaitu pembiayaan murabahah yang dilakukan dalam jangka waktu tertentu serta ada kewajiban dari pihak nasabah untuk membayar angsuran sesuai dengan akad. Sehingga pengakuan margin diakui pada saat nasabah melakukan pembayaran angsuran bukan saat penyeraha persediaan murabahah."

Pada penyajian BRIS Cabang Malang telah sesuai dengan PSAK 102 dimana BRIS menyajikan piutang murabahah pada posisi debet serta diposisi kredit terdapat margin murabahah ditangguhkan. Pernyataan ini di dukung dengan pengamatan peneliti pada laporan keuangan BRIS.

Pada pengungkapan BRIS Cabang Malang sudah sesuai dengan PSAK 102 dimana BRIS mengungkapkan hal-hal terkait transaksi murabahah tetapi terbatas seperti: harga perolehan asset murabahah, janji pemesanan dalam murabahah berdasarkan pesanan sebagai kewajiban atau bukan dan pengungkapan yang diperlukan sesuai PSAK 101: Penyajian Laporan Keuangan Syariah.

Dewan Syariah Nasional menghalalkan transaksi dengan akad murabahah yang mengakui margin secara anuitas ataupun proposional (Harianto et al., 2014; Nurdin \& Jariah, 2021; Ramadani \& Suprayogi, 2017). Fatwa ini terdapat dalam fatwa DSN MUI: No.84/DSN-MUI/XII/2012 tentang Metode Pengakuan Keuntungan Al-Tamwil Bi Al-Murabahah, maka BRIS Cabang Malang telah menjalankan transaksi akad murabahah sesuai fatwa 
MUI. Serta sesuai dengan akad jual beli yang terdapat dalam surat AlBaqarah ayat 275 yang memiliki terjemahan :

“...Dan Allah telah menghalalkan jual beli dan mengharamkan riba..."

\section{KESIMPULAN}

Pada masa pandemi Covid-19 pembiayaan murabahah menjadi pembiayaan yang paling diminati oleh nasabah BRIS Cabang Malang, karena nasabah membutuhkan asset untuk tetap bertahan hidup. BRIS Cabang Malang menggunakan akad murabahah dan mengakui margin secara proposional saat nasabah membayar angsuran hal ini sesuai dengan Fatwa DSN MUI: No.84/DSN-MUI/XII/2012 tentang Metode Pengakuan Keuntungan Al-Tamwil Bi Al-Murabahah tentang pengakuan margin murabahah halal menggunakan anuitas atau proposional. PSAK 102 menjelaskan bahwa metode pengakuan margin diakui secara proposional hal ini sesuai dengan BRIS telah mengakui margin murabahah yaitu secara proposional ketika nasabah membayar angsuran.

\section{DAFTAR PUSTAKA}

Amrullah. (2016). Analisis Penerapan PSAK No. 102 Tentang Akuntansi Murabahah (Studi Kasus Pada Lembaga Keuangan Mikro Syari'ah Baitul Qiradh Afdhal Cabang Kota Lhokseumawe). Jurnal Ilmiah Mahasiswa Ekonomi Akuntansi (JIMEKA), 1(1), 341-356.

Anik, A. (2017). Faktor Yang Berpengaruh Terhadap Margin Murabahah Pada Bank Syariah Mandiri Periode 2013-2015. Jurnal Ilmiah Ekonomi Islam, 3(01), 87. https://doi.org/10.29040/jiei.v3i01.102

Awwalunnisa, N. (2021). Peran Lembaga Keuangan Syariah Dalam Pengentasan Kemiskinan Di Provinsi Nusa Tenggara Barat. Iqtishaduna, 12(1), 29-47. https://journal.uinmataram.ac.id/index.php/ iqtishaduna/article/view/3283

Bramantyo, R. Y., \& Rahman, I. (2021). Implementasi New Normal Dan Perubahan Sosial Di Indonesia. Pengabdian Masyarakat Fakultas Hukum Universitas Kadiri. Dinamika Hukum \& Masyarakat, 3, 2.

BRISyariah. (2020). https://www.brisyariah.co.id/, diakses pada 20 Desember 2020.

Farid, M. (2013). Murabahah Dalam Perspektif Fikih Empat Mazhab. Epistemé: Jurnal Pengembangan Ilmu Keislaman, 8(1). https://doi.org/10.21274/epis.2013.8.1.113-134

Fatmawati, E. E., \& Mulawarman, A. D. (2014). Perlakuan Akuntansi Akad Murabahah Berbasis Margin Anuitas Pada BMT Sunan Kalijogo. Jurnal Ilmiah Mahasiswa FEB, 3(1), 1-14.

Habibah, M., \& Nikmah, A. (2017). Analisis Penerapan Akuntansi Syariah Berdasarkan Psak 102 Pada Pembiayaan Murabahah Di Bmt SeKabupaten Pati. Equilibrium: Jurnal Ekonomi Syariah, 4(1), 114. 
https://doi.org/10.21043/equilibrium.v4i1.1842

Harianto, S., Negeri, P., \& Aceh, L. (2014). Al - Tamwil Bi Al-Murāba ' Ah Di Ksps. Iqtishadia, 7(1), 111-134.

Hidayat, A. T., \& Nurhayati, N. (2018). Tinjauan PSAK 102 Penerapan Akuntansi Murabahah Dalam Pembiayaan Kredit Kepemilikan Rumah. JAD: Jurnal Riset Akuntansi \& Keuangan Dewantara, 1(1), 1-10. https://doi.org/10.26533/jad.v1i1.191

Kamaliyah, F. (2018). the Influence of Margin Murabaha Recognition Methotd on Islamic Banking Sustainability. Eaj (Economics and Accounting Journal), 1(3), 206. https://doi.org/10.32493/eaj.v1i3.y2018.p206-214

Marimin, A., \& Romdhoni, A. H. (2017). Perkembangan Bank Syariah Di Indonesia. Jurnal Ilmiah Ekonomi Islam, 1(02), 75-87. https://doi.org/10.29040/jiei.v1i02.30

Mastura, \& Santaria, R. (2020). Dampak Covid 19 terhadap Proses Pengajaran bagi Guru dan Siswa. Jurnal Studi Guru Dan Pembelajaran, 3(2), 289294.

Muchlis, S. (2019). Syari'ah Optimization Of Business Theory In Preventing Riba Practices In Murabahah Contract (Case Study at Muamalat Indonesian Bank). International Journal of Islamic Business Ethics, 4(1), 563. https://doi.org/10.30659/ijibe.4.1.563-581

Nawawi, I. (2012). Fikih Muamalah Klasik Kontemporer. Bogor: Ghalia Indonesia. Ghalia Indonesia.

Nurdin, R., \& Jariah, S. A. (2021). Analisis Rate Margin Murabahah Pada Transaksi Jual Beli Rumah Subsidi Kpr Btn Syariah Dalam Perspektif Hukum Islam (Suatu Penelitian Pada BTN Syariah KC Banda Aceh). Jurnal Al-Mudharabah, 3(1), 27-40.

Octariza, H. (2018). Analisis Metode Anuitas dan Proporsional Murabahah Pada Bank Syariah. repository.uinjkt.ac.id.

http://repository.uinjkt.ac.id/dspace/handle/123456789/41031

Oktaviani Satriyanti, E. (2012). Pengaruh Kualitas Layanan, Kepuasan Nasabah Dan Citra Bank Terhadap Loyalitas Nasabah Bank Muamalat Di Surabaya. Journal of Business and Banking, 2(2), 171. https://doi.org/10.14414/jbb.v2i2.172

Pratiwi, I. E., \& Septiarini, D. F. (2014). Analisis Penerapan Psak 102 Murabahah (Studi Kasus Pada KSU BMT Rahmat Syariah Kediri). AKRUAL Jurnal Akuntansi, 6(1), 17-32. https://doi.org/10.26740/jaj.v6n1.p17-32

Qiyamah, S. N. (2015). Analisis Perhitungan Margin Murabahah pada Produk Piutang Murabahah (Studi Kasus pada BMT Al-Fath IKMI). Jurnal Eonomi Syariah.

Ramadani, D. W., \& Suprayogi, N. (2017). Analisis Perbedaan Penggunaan Metode Pengakuan Pendapatan Margin Murabahah Terhadap Kualitas Laba (Studi Kasus pada Bank Syariah di Indonesia Tahun 2011-2013). Jurnal Ekonomi Syariah Teori Dan Terapan, 3(9), 699. https://doi.org/10.20473/vol3iss20169pp699-712

Safitri, A. N., Fasa, M. I., \& Suharto, S. (2021). Dampak Pandemi Covid-19 terhadap Perkembangan dan Prospek Perbankan Syariah. Economics 
Awin Rahma Zulvia: Implementasi Akad Murabahah Berbasis Margin

and Digital Business Review, 2(2), 103-177.

https://doi.org/10.37531/ecotal.v2i2.66

Sholikah, A. M., \& Miranti, T. (2020). Factors influence financial sustainability banking in Indonesia. Jurnal Ekonomi Dan Bisnis Islam, 6(1), 41-50. http://repository.uin-malang.ac.id/8334/

Soemitra, A. (2017). Bank \& Lembaga Keuangan Syariah. Prenada Media. Prenada Media.

SPS. (2020). Statistik Perbankan Syariah Juni 2020. Otoritas Jasa Keuangan. https://www.ojk.go.id/id/kanal/syariah/data-dan-statistik/statistikperbankan-syariah/Pages/Statistik-Perbankan-Syariah---Desember2020.aspx

Triningsih, F. (2021). Analisis Dampak Covid-19 Terhadap Pendapatan Lembaga Keuangan Syariah. repository.iain-tulungagung.ac.id

Wiroso. (2010). Transaksi Akuntansi Syariah. Ikatan Akuntan Indonesia. 